\title{
Increased phenylpropanoids production in UV-B irradiated Salvia verticillata as a consequence of altered genes expression in young leaves
}

Marziye Rahimi Rizi ${ }^{\mathrm{a}}$, Mohammad Sayyari ${ }^{\mathrm{a}}$, Asghar Mirzaie-Asl ${ }^{\mathrm{b}}$, Lucio Contic ${ }^{\mathrm{c}}$ Ali Azizi ${ }^{\mathrm{a} *}$

\footnotetext{
a Department of Horticultural Science, Bu-Ali Sina University, Hamedan, Iran.

${ }^{\mathrm{b}}$ Department of Biotechnology, Bu-Ali Sina University, Hamedan, Iran

${ }^{c}$ Department of Biosciences, Università Degli Studi di Milano, Milano, Italy
}

*Corresponding Author: Azizi@basu.ac.ir

ORCID ID: 0000-0002-4089-7735

\begin{abstract}
Ultraviolet-B (UV-B) radiation as an environmental potential elicitor induces the synthesis of plant secondary metabolites. The effects of UV-B radiation on photosynthetic pigments and dry weight, biochemical and molecular features of old and young leaves of Salvia verticillata were investigated. Plants were exposed to $10.97 \mathrm{~kJ} \mathrm{~m}^{-2}$ day $^{-1}$ of biologically effective UV-B radiation for up to 10 days. The sampling process was performed in four steps: 1, 5, 10, and 13 days (recovery time) after the start of irradiation. As a result of plant investment in primary and secondary metabolism, the production of phenolic compounds increased, while chlorophyll levels and leaf dry weight (\%) declined. Under long-term UV-B exposure, young leaves exhibited the most significant reduction in chlorophyll a and $b$ content and leaf dry weight. The highest level of total phenol (1.34-fold) and flavonoid concentration (2-fold) relative to the control was observed on the $5^{\text {th }}$ day and recovery time, respectively. Young leaves demonstrated the highest amount of phenolic acids in recovery time. Young leaves on the $5^{\text {th }}$ day of the experiment exerted the highest level of antioxidant activity when compared to the control. A positive correlation was observed between antioxidant activity and the amount of phenolic compounds. Regarding the expression of phenylpropanoid pathway genes, UV-B enhanced the expression of phenylalanine ammonialyase, tyrosine aminotransferase, and rosmarinic acid synthase with the highest level in young leaves on the $10^{\text {th }}$ day. Overall, young leaves of S. verticillata indicated higher sensitivity to $\mathrm{UV}-\mathrm{B}$ radiation and developed more tangible reactions to such radiation.
\end{abstract}

Key words: Salvia verticillata, UV-B, phenolic acids, antioxidant activity, gene expression 


\section{Introduction}

Ozone depletion in recent years has led to more UV radiation reaching the Earth's surface compared to the past (McKenzie et al., 2003; Zhang et al., 2017). Even though it is predicted that the ozone layer will improve in the next years, the forecast about ultraviolet light is less reliable (McKenzie et al., 2009). Although sunlight plays a vital role in the growth and development of plants as an environmental factor, its ultraviolet spectrum can lead to abiotic stress signaling in plants. Ultraviolet radiation through disruption in the electron transfer of the photosynthetic system and increase in the activity of NADPH peroxidases and oxidases triggers the production of ROS (Müller-Xing et al., 2014). UV-B radiation can significantly contribute to the growth, developmental (Esringu et al., 2016), biological (Ghasemi et al., 2019), and morphological (Hopkins et al., 2002) responses in plants. Some studies reported positive effects of UV-B radiation on the accumulation of the bioactive compounds of medicinal plants (Chen et al., 2018; Ghasemi et al., 2019; Kumari and Prasad, 2013; Sun et al., 2010). Actually, plants react differently to ultraviolet light applying the mechanisms of avoidance, tolerance, and neutralization (Hofmann et al., 2003). Plants also employ protection mechanisms including secondary metabolites biosynthesis and accumulation of UV absorbing compounds against UV-B radiations, such as flavonoids and phenolic acids which have beneficial effects on human health as well (Csepregi et al., 2017; Dolzhenko et al., 2010; Farah and Donangelo, 2006; Ghasemzadeh et al., 2016; Guo et al., 2011; Zhang et al., 2017). Flavonoids are located in the mesophilic cells of plants and acts as a defensive system against biotic and abiotic stresses. Besides, the positive effect of flavonoids on human health has been attributed to their high antioxidant activity (Ye et al., 2017). In addition to flavonoids, hydroxycinnamic acids can be an efficient screening agent against UV-B radiation, as they absorb the UV-B spectral region very effectively in Arabidopsis (Kolb et al., 2001). The increase in the amount of these compounds is due to alterations in the level of genes expression of the phenylpropanoid pathway such as PAL (Mackerness, 2000; Shamala et al., 2020). Most of the key genes involved in the biosynthetic pathway of phenolic acids, phenylalanine ammonia-lyase (PAL), tyrosine aminotransferase (TAT), and rosmarinic acid synthase (RAS), are affected by different elicitors such as UV radiation (Shi et al., 2019). It is worth mentioning that, RA is a predominant phenolic acid in the Lamiaceae family to which numerous bioactive properties ,including antiviral, antibacterial, anti-inflammatory, antioxidant, have been attributed (Huang et al., 2008; Kwon et al., 2020). Also, it has great 
potential as a therapeutic agent for Alzheimer's and vascular dementia diseases (Rahmani et al., 2020).

In recent years, the tendency to use drugs from natural resources has led researchers to pay more attention to medicinal plants. On the one hand, the fewer side effects of these plants and on the other hand, their greater compatibility with the human body compared to chemical drugs have increased their importance in the pharmaceutical industry (Ghasemi et al., 2019; Kowalski et al., 2019; Zahra et al., 2020). Furthermore, the therapeutic potential of chemical compounds of medicinal plants has led to their direct and indirect application in drug production (Klein et al., 2018; Kumari and Prasad, 2013). The presence of important bioactive compounds such as hydrocynamic acids, particularly salvianolic acids and RA in the Lamiaceae family, has made it a potential candidate for the production of herbal medicines (Mosadegh et al., 2018).

The genus Salvia, with 17 endemic species in Iran, is considered to be one of the greatest genera of Lamiaceae (Ziba Jamzad, 2012). This genus exhibits various remarkable biological activities, including antioxidant, antibacterial, antifungal, antimicrobial, antitumor, antidiabetic, antituberculosis, antiplasmodial, anti-inflammatory (Ebrahimabadi et al., 2010; Flores-Bocanegra et al., 2017; Fotovvat et al., 2019; Hamidpour et al., 2014). A broad range of terpenoids and polyphenolics (including CA and its derivatives such as RA and salvianolic acids) were detected in Salvia spp. (Esmaeilizadeh, 2017; Ghorbani and Xu et al., 2018; Jassbi et al., 2016; Katanić Stanković et al., 2020; Topçu, 2006). The Salvia plants have long been utilized in traditional medicine and due to having powerful pharmaceutical and healthcare effects are well-known as valuable sources in the field of medicines production (Rahmani et al., 2020). The therapeutic impacts of these plants have mainly assigned to the presence of pharmacologically active compounds such as phenolic acids, flavonoids and terpenes (Koutsoulas et al., 2019).

Among the twenty-seven investigated Salvia species, Salvia verticillata demonstrated the highest content of RA (Fotovvat et al., 2019). S. verticillata has been used in the production of cheese with a special taste and the preservation of cheese and meat products. Its aerial parts have also been used traditionally as expectorant and cataplasm. S. verticillata, a rich source of RA, has received less attention in modern food and medicine industries. However, the presence of polyphenolic compounds, especially RA, with antioxidant, antimicrobial and biocompatible properties, has made $S$. verticillata a valuable resource in the pharmaceutical, cosmetics and food industries (Katanić Stanković et al., 2020). 
While some research has been carried out on S. verticillata, no studies have been found on its ability to tolerate UV-B radiation, so that is why the plant was chosen. The purpose of the present investigation was to test the following hypotheses: (1) UV-B radiation can induce eustress and lead to accumulative responses in plants without causing severe damage; (2) UV-B radiation leads to enhance and accumulate phenolic compound in S. verticillata by increasing the expression of phenylpropanoid pathway genes; (3) There exist differences in the accumulation of phenolic compounds between old and young leaves of S.verticillata when exposed to UV-B radiation. Such an approach allowed us to determine the UV-B impacts on phenolic compounds and antioxidant activity of extracts and expression of key genes in the pathway of rosmarinic acid synthesis in S.verticillata plant.

\section{Materials and methods}

\subsection{Plant materials and UV-B exposure}

The seeds of $S$. verticillata were collected from Pil village border, Haraz Road, Mazandaran province, Iran. The plant species was identified by Dr. Ranjbar (Department of Biology, BuAli Sina University, Hamedan, Iran). Voucher specimen (Voucher number: 42812) was protected at the Laboratory of Plant Systematics, Department of Biological Sciences, Bu-Ali Sina University, Hamedan, Iran. To provide plant samples, S.verticillata seeds were sown in cavity trays (1:1:1 vermicompost: perlite: coco peat) and maintained in a greenhouse. Seed

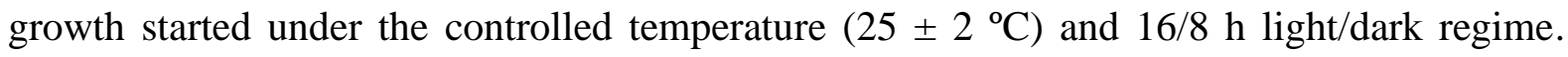
Seedlings were transplanted into individual pots when they reached the true four-leaf stage. Before the flowering phase, Six-month-old young plants were exposed to UV-B radiation for 1hour per day for ten days (between 11 AM to 12 PM). The lamps were held at an equal distance $(20 \mathrm{~cm})$ above the plants and diagonally in the left and right of the plants in the greenhouse. UV-B radiation was applied for the 1-hour exposure from 3 lamps (Phillips, TL 40W/12, 290-315 nm, peak at $302 \mathrm{~nm}$ ), giving a total biologically UV-B dose of $10.97 \mathrm{~kJ} \mathrm{~m}^{-2}$ day $^{-1}$. In order To exclude the effect of shorter wavelengths $(<290 \mathrm{~nm}), 0.1 \mathrm{~mm}$-thick cellulose diacetate sheets (Cadillac Plastic Co., Baltimore, MD, USA) were used. The intensity of the radiation was $0.6 \mathrm{Wm}^{-2}$ for each lamp that was approximately 6-fold ambient. The UV radiation intensity was measured using an ultraviolet intensity meter (Hagner, EC1X UV-B, Sweden). The photosynthetic active radiation was roughly $500 \mu \mathrm{mol}$ photons $\mathrm{m}^{-2} \mathrm{~s}^{-1}$ at midday. Control plants were kept in the same condition without UV-B radiation; therefore 
control plants were exposed by lamps covered with polyester filters $(0.1 \mathrm{~mm}$, Shanghai Plastic Company, China) for UV-B radiation exclusion.

During the experiment, the homogeneity of the UV-B radiation emitted by the lamps was checked by a power detector with a UV sensor (818-UV/DB, Newport, Irvine, CA, USA). Abbreviations for UV-B treatment are represented in Table 1. The experiment was conducted in a completely randomized design with three repetitions for each treatment. The variance analysis results are shown in the supplementary information as Table S1.

\subsection{Sample collection}

To investigate biochemical and gene expression changes, sampling from healthy young and old leaves was performed from plants with $10 \mathrm{~cm}$ in height. Three young and three old leaves were collected from each plant. Sampling were done in two stages, the first stage was on the $1^{\text {st }}, 5^{\text {th }}$, and $10^{\text {th }}$ days of the experiment in parallel with UV-B exposure and the second section was on 3 days after UV-B radiation removal (13th day of experiment, recovery time). Completely developed leaves from the upper part of the plant were regarded as young leaves. While non-senescent leaves from the lower part (node 3-5) were represented as old leaves. Leaves were immediately frozen in liquid nitrogen and then stored at $-80{ }^{\circ} \mathrm{C}$ until molecular analysis. In order to study biochemical changes and measure dry weight (\%), samples were dried at room temperature and darkness. The weight of the samples was measured every 48 hours using an electronic scale until the weight of samples remained constant, and the final weight was considered as dry weight. Biochemical analyses were done shortly (Approximately one week) after drying to eliminate possible environmental effects (temperature, light, storage time) on the bioactive compounds.

Table 1. Abbreviations for UV-B treatment in young and old leaves of S.verticillata

\begin{tabular}{lll}
\hline Abbreviation & Explanation & Day of sampling \\
\hline UYL1 & UVB treatment at young leaf & 1 \\
UYL5 & UVB treatment at young leaf & 5 \\
UYL10 & UVB treatment at young leaf & 10 \\
UYL13 & UVB treatment at young leaf & 13 \\
UOL1 & UVB treatment at old leaf & 1 \\
UOL5 & UVB treatment at old leaf & 5 \\
UOL10 & UVB treatment at old leaf & 10 \\
UOL13 & UVB treatment at old leaf & 13 \\
CYL1 & Control young leaf & 1 \\
CYL5 & Control young leaf & 5 \\
CYL10 & Control young leaf & 10 \\
CYL13 & Control young leaf & 13 \\
COL1 & Control old leaf & 1 \\
COL5 & Control old leaf & 5 \\
COL10 & Control old leaf & 10 \\
COL13 & Control old leaf & 13 \\
\hline
\end{tabular}




\subsection{Determination of chlorophylls (a and b) content}

For measure content of $\mathrm{Chl} a$ and $\mathrm{b}$, fresh leaf samples (100 mg) were used. Samples were homogenised with acetone ( $80 \% \mathrm{v} / \mathrm{v})$ and then centrifuged at $10000 \times \mathrm{g}$ for $10 \mathrm{~min}$ and made up to a final volume of $10 \mathrm{~mL}$. The absorbance of extract was read at 663.2 and $646.8 \mathrm{~nm}$. Content of Chl a, b and total Chl was calculated using the formula (Lichtenthaler, 1987) given below:

\section{$\operatorname{Chl~a~}\left(\mathrm{mg} \mathrm{g}^{-1} \mathrm{FW}\right)=$ \\ (12.25 A663.2 - 2.79 A646.8) $\times$ volume of supernatant/sample mass (g) $\operatorname{Chl~b}\left(\mathrm{mg} \mathrm{g}^{-1} \mathrm{FW}\right)=$ \\ (21.50 A646.8 - 5.1 A663.2) × volume of supernatant/sample mass (g) Total Chl $\left(\mathrm{mg} \mathrm{g}^{-1} \mathrm{FW}\right)=$ \\ (7.15 A663.2 + 18.71 A646.8) $\times$ volume of supernatant /sample mass (g)}

\subsection{Ultrasound-assisted extract preparation}

Plant materials were dried at room temperature away from sunlight and then $250 \mathrm{mg}$ of the dried plants were powdered in liquid nitrogen by mortar and pestle. Extraction with ultrasound has been applied extensively in the past few decades as an effectual extraction method in various industries, such as the food and pharmaceutical industries (Xu et al., 2017). Accordingly, to prepare the aqueous-methanolic extract, $200 \mathrm{mg}$ of the powdered dried leaf was mixed with $2 \mathrm{~mL} \mathrm{80 \%} \mathrm{methanol} \mathrm{and} \mathrm{placed} \mathrm{in} \mathrm{an} \mathrm{ultrasonic} \mathrm{bath} \mathrm{(40} \mathrm{khz,} \mathrm{AVA-UB} \mathrm{5-}$ 20, AVA TEKS, Iran) at $40^{\circ} \mathrm{C}$ for 45 minutes. The mixture was filtered through Whatman No.4 paper. The extracts were stored at $-20^{\circ} \mathrm{C}$ until further experiments.

\subsection{Determination of total phenol concentration}

The TPC of extracts was evaluated based on the method represented by Kocak et al. (2016). Briefly, $0.25 \mathrm{~mL}$ of extract solution was mixed with $1 \mathrm{~mL}$ diluted Folin-Ciocalteu reagent (1:9) and shaken vigorously. After $3 \mathrm{~min}, 0.75 \mathrm{~mL}$ of $1 \% \mathrm{Na} 2 \mathrm{CO} 3$ solution was added. Then, the mixture was incubated for $2 \mathrm{~h}$ in a shaker at room temperature and in the dark. The absorbance of the reaction was read at $760 \mathrm{~nm}$ using a UV-visible spectrophotometer (UV1280, UV-VIS, Shimadzu, Japan). The TPC was declared as the equivalent milligrams of gallic acid per $1 \mathrm{~g}$ of dried weight (mg GAE. $\mathrm{g}^{-1} \mathrm{DW}$ ). 


\subsection{Determination of total flavonoid concentration}

To measure the TFC of extracts, the colorimetric method (Zhang et al., 2017) was used, with slight modification. $1 \mathrm{~mL}$ of the extract solution was mixed with $0.7 \mathrm{~mL}$ of $5 \%$ sodium nitrate solution and reacted for $7 \mathrm{~min}$. Then, $0.3 \mathrm{~mL}$ of $10 \%$ aluminum chloride was mixed with the solution. After $6 \mathrm{~min}, 5.0 \mathrm{~mL}$ of 1M/L sodium hydroxide solution was added to the mixture. The sample absorbance was measured after $15 \mathrm{~min}$ at $510 \mathrm{~nm}$ using a UV-visible spectrophotometer (UV- 1280, UV-VIS, Shimadzu, Japan). The TFC concentration was expressed as the equivalent milligrams of quercetin per $1 \mathrm{~g}$ of dried weight (mg QE. $\left.\mathrm{g}^{-1} \mathrm{DW}\right)$.

\subsection{Evaluation of antioxidant activity}

The effect of the methanolic extracts on free radicals scavenging was examined in a methanolic solution of DPPH (Kocak et al., 2016). $0.5 \mathrm{~mL}$ of extract solution was added to 2 $\mathrm{ml}$ of $0.004 \% \mathrm{DPPH}$ solution. The mixture was placed at room temperature in the dark for 30 min. Then, sample absorbance was measured at $517 \mathrm{~nm}$ by a UV-visible spectrophotometer (UV- 1280, UV-VIS, Shimadzu, Japan). The DPPH free radical scavenging activity of extracts was calculated by using the following equation:

$\mathrm{DPPH}$ scavenging effects $(\%)=[(\mathrm{A} 0-\mathrm{A} 1 / \mathrm{A} 0) \times 100]$

A0, the DPPH absorbance in the absence of extract; A1, the DPPH absorbance in the presence of extract.

\subsection{HPLC analysis and identification of phenolic acids}

Phenolic acids were evaluated by RP-HPLC (Knauer Scientific Instruments, Berlin, Germany) according to the method of Luis et al. (2007), with modification. Detection and quantification were carried out with a Smartline Pump 1050, a Smartline UV Detector 2600, DGU-14A degasser. Before injection, all the solutions were filtered through a $0.45 \mathrm{~nm}$ filter. Aliquots $(80 \mu \mathrm{l})$ were injected into a C18 reversed-phase column $(250 \mathrm{~mm} \times 4.6 \mathrm{~mm}$ length, 5 $\mu \mathrm{m}$ particle size). All solvents used for extraction and identification of phenolic acids were HPLC grade.The separation was achieved using the gradient acetonitrile (solvent A) and acidified water containing $2.5 \%$ of acetic acid (solvent B). The gradient was as follows: 0 $\min , 10 \% \mathrm{~A}, 0.5 \mathrm{~mL} \mathrm{~min}{ }^{-1} ; 15 \min , 60 \% \mathrm{~A}, 0.5 \mathrm{~mL} \mathrm{~min}^{-1} ; 35 \mathrm{~min}, 60 \% \mathrm{~A}, 0.3 \mathrm{~mL} \mathrm{~min}^{-1} ; 50$ $\min ; 10 \% \mathrm{~A}, 0.5 \mathrm{~mL} \mathrm{~min}{ }^{-1}$. After $50 \mathrm{~min}$, the gradient was held for $10 \mathrm{~min}$ before a new injection. The detection was set at $280 \mathrm{~nm}$. The identification of phenolic acids was based on a comparison of the real retention time to those of authoritative standards. The standards used 
were as following: CGA $\left(\mathrm{y}=110981 \mathrm{x}-2 \mathrm{E}+06, \mathrm{R}^{2}=0.9908\right), \mathrm{CA}\left(\mathrm{y}=109732 \mathrm{x}-1 \mathrm{E}+06, \mathrm{R}^{2}\right.$ $=0.9903)$, RA $\left(y=121392 x-748780, R^{2}=0.99\right)$ and SAA $\left(y=73704 x-996822, R^{2}=\right.$ 0.9872). The results were expressed in $\mathrm{mg}$. $\mathrm{g}^{-1} \mathrm{DW}$.

\subsection{RNA extraction and synthesis of cDNA}

In order to extract RNA from the samples, leaves $(100 \mathrm{mg})$ were ground in liquid nitrogen by mortar and pestle, and RNA was extracted by RNX-Plus solution (Sinaclon, Iran). To prepare DNA-free RNA, RNAs were treated with DNase (DNase 1, Rnase-free, Sinaclon, Iran). The concentration and purity of total RNA were determined using ScanDrop (2000, Thermo Scientific, USA). The ratios of the A260/280 and A260/230 were considered to evaluate the purity of RNA. The quality of RNA was tested by $1.0 \%$ agarose gel electrophoresis. The high-purity RNA (260/280nm absorbance ratio about 2.0 and 260/230 nm absorbance ratio 2-2.2) was used to synthesize cDNA (cDNA Synthesis kit, Yekta Tajhiz Azma, Iran) according to the manufacturer's protocol $\left(5 \mathrm{~min}\right.$ at $70{ }^{\circ} \mathrm{C}, 60 \mathrm{~min}$ at $42{ }^{\circ} \mathrm{C}$ and followed by 5 min at $70{ }^{\circ} \mathrm{C}$ ). cDNAs were maintained in $-20^{\circ} \mathrm{C}$ for RT-qPCR.

\subsection{Real-time quantitative PCR analysis}

The $P A L$-specific cDNA (815 bp) was amplified and sequenced. The $P A L$-related sequence was deposited in the GeneBank databse, National Center for Biotechnology Information, with accession number MT212192. Then, specific primers were designed for this PAL gene. Primers for TAT gene were designed on homologous sequences selected of the genus Salvia using Primer-Blast software. We used Ubiquitin as an internal control according to the study of Yang et al. (2010) that showed the Actin and Ubiquitin as reference genes were the most stable than the other genes studied in the Salvia. The list of the sequences of the primers used is shown in Table 2.

Primers were checked by PCR with the cDNA as a template before using in real-time (RT)PCR. RT-qPCR was done using TB Green Premix Ex TaqII (TaKaRa, Japan) conforming to the producer manual: preliminary denaturation at $95{ }^{\circ} \mathrm{C}$ for $30 \mathrm{~s}$ ( 1 cycle); 40 cycles consisting of denaturation at $95{ }^{\circ} \mathrm{C}$ for $5 \mathrm{~s} ; 30 \mathrm{~s}$ at the annealing temperature. Finally, the $\mathrm{Ct}$ values obtained from RT-qPCR instrument software were used to calculate the relative expression of the genes by $2^{-\Delta \Delta \mathrm{CT}}$ method (Livak and Schmittgen, 2001). For each sample, $\mathrm{Ct}$ values of the reference genes were used as an internal control to normalize target gene expression. 
Table 2. Gene-specific primers used for gene expression analysis in S.verticillata by RT-qPCR.

\begin{tabular}{llll}
\hline Gene & Primers & Sequence $\left(5^{\prime} \rightarrow 3^{\prime}\right)$ & Reference \\
\hline SvPAL & Forward & GATTTGAGGCATTTGGAGGA & This work \\
& Reverse & GCCCATTGTGAGAGTTCGTT & \\
SvTAT & Forward & CGATGAGGTCTACGGCCATC & This work \\
& Reverse & CAGCCAGGAACCAACCATCT & \\
SvRAS & Forward & CAGTTGACTCGGTTCAAATGCGG & (Rahmani et al., 2020) \\
& Reverse & TGATGAAGTGGAGAGCGGAG & \\
Ubiquitin & Forward & GTTGATTTTTGCTGGGAAGC & (Yang et al., 2010) \\
& Reverse & GATCTTGGCCTTCACGTTGT & \\
\hline
\end{tabular}

\subsection{Statistical analysis}

Data obtained from biochemical experiments were analyzed using SAS software (ver. 9.4). The normality was checked by the Shapiro-Wilk test before we used data for the statistical analysis. Duncan's multiple range test was used to compare the means. Differences were considered statistically significant when $\mathrm{P} \leq 0.01$. Pearson correlation coefficient was used for the correlation determination between the phenolic compound and radical scavenging capacity of methanolic extracts of S.verticillata. All of the figures and a heatmap were provided by GraphPad Prism 8 software. A heatmap is a graphical representation of data where the individual values contained in a matrix are represented as colors.

\section{Results and discussion}

\subsection{Changes in the content of chlorophyll a and $b$ in S.verticillata leaves under UV-B exposure}

The results revealed that the duration of UV-B radiation has differently influenced the contents of chlorophylls in treated leaves of S. verticillata (Table 3). Exposure of the leaves to a short time of UV-B (1 day) did not significantly affect Chl a content in young and old leaves, While the Chl a content decreased in UYL on the $5^{\text {th }}$ and $10^{\text {th }}$ days, $23.6 \%$ and $28.57 \%$ compared to the control, respectively. By increasing the duration of UV radiation, the $\mathrm{Chl}$ a content in old leaves was also significantly affected, $17.39 \%$ and $22.47 \%$ decline compared to the control on the $5^{\text {th }}$ and 10th days, respectively. Although a decrease in chlorophyll content in both kinds of leaves was found, this decrease was more considerable in young leaves. It suggests that young leaves were more UV-B-sensitive than old leaves and the age of leaves was a vital factor for Chl a content. After removing UV-B radiation, the 
amount of Chl a in young and old leaves increased compared to UVB-exposed leaves for ten days. However, control plants showed higher Chl a level on day 13 in comparison to UOL13 and UYL13. As shown in the Table 3, the Chl b content immediately decreased on the first day after UV-B irradiation in young leaves, compared to control plants. It was evident that $\mathrm{Chl} \mathrm{b}$ content in the treated leaves was more sensitive than that of $\mathrm{Chl}$ a to the duration of UV-B radiation changes. With increasing UV-B radiation duration, the decrease of $\mathrm{Chl} b$ in young leaves continued. The UYL10 showed the highest reduction (55.38\%) of Chl b content. In old leaves, a considerable reduction in the $\mathrm{Chl} \mathrm{b}$ content was observed on the $5^{\text {th }}$ $(29.23 \%)$ and $10^{\text {th }}(29.23 \%)$ after irradiation of UV-B. In recovery time, the Chl b content in young and old leaves increased, and UOL13 did not show a significant difference compared to COL13.

Kamble et al. (2015) reported that almost in all studied plants, Chl a had more concentration than that of $\mathrm{Chl} \mathrm{b}$. They pointed out $\mathrm{Chl} \mathrm{a}$ and $\mathrm{b}$ as primary and accessory pigments, respectively. UV-B may impress on the chlorophyll synthesis or degradation through stimulation of ROS generation. $\mathrm{Chl} a$ and $\mathrm{b}$ contents decreased in the treated plants at a slower rate from the $5^{\text {th }}$ to the $10^{\text {th }}$ day. It is assumed that the increase in flavonoids, a UV-B protection strategy during this period, has prevented the degradation of photosynthetic pigments by neutralizing ROS. As expected, the total chlorophyll content also decreased under UV-B radiation. A significant decrease in total chlorophyll was observed in young leaves after the first day of UV irradiation, while old leaves were less affected by UV radiation. In the irradiated leaves, the highest and lowest total chlorophyll content (1.47 and $0.94 \mathrm{mg} . \mathrm{g}^{-1} \mathrm{FW}$ ) was observed in UOL1 and UYL10, respectively. Although exposure to UV-B decreased the chlorophylls contents, the ratio of $\mathrm{Chl} a / b$ contents significantly increased in UYL and the highest ratio of $\mathrm{Chl}$ a/b contents was obtained in UYL10 $(2.21 \pm$ 0.12). The ratio of $\mathrm{Chl} \mathrm{a} / \mathrm{b}$ contents in UOL1, 5 and 10 increased compared to the control, although it was not significant. Takshak and Agrawal (2015) suggested that UV-B leads to impairment in the photosynthetic system, and the rate of photosynthesis may decrease. Furthermore, plants divert photosynthesis towards the synthesis of antioxidative defense compounds and enzymes to counteract the effects of stress. In agreement with our findings, a decrease of chlorophyll content under UV-B has also been reported in some plants such as Jaborosa magellanica (Cuadra et al, 2004), Capsicum annuum (Mahdavian et al, 2007), Artemisia annua (Pandey and Pandey-Rai, 2013), Prunella vulgaris (Zhang et al., 2017) and Crepidiastrum denticulatum (Park et al., 2020). It seems that the difference in chlorophyll content of old and young leaves can relate to their anatomy characteristics. The number of 
palisades and spongy parenchyma cell layers may affect chlorophylls contents. Martins et al. (2017) reported higher values of palisade parenchyma in adult leaves of Salvia officinalis L. var. purpurascens. Given that palisade parenchyma contains many chloroplasts, it is likely that a higher amount of chlorophyll in older leaves is due to the higher the rate of spongy parenchyma. Knowledge of anatomical differences of S.verticillata old and young leaves may be useful in interpreting physiological changes with age.

\subsection{Changes in dry weight (\%) in S.verticillata leaves under UV-B exposure}

As shown in the Table 3, in both control and irradiated plants, the old leaves presented a lower leaf dry weight $(\%)$ than the young leaves. In the $1^{\text {st }}$ and $5^{\text {th }}$ days, UV-B radiation reduced the dry weight in the old and young leaves, but this difference was not statistically significant. In irradiated plants, reduction of the dry weight in young leaves was more than in old leaves, and the highest dry weight reduction was observed in UYL10. The dry weight of UYL10 decreased by $21.38 \%$ compared to CYL10. At the same time, CYL10 provided the highest percentage of dry weight $(23.57 \pm 3.65)$. The dry weight of UOL13 and UYL13 increased compared to UOL10 and UYL10, but this increase was not significant. Considering that in both control and irradiated plants, the old leaves presented less dry weight, so it can be said that the old leaves had higher water content. As a result of UV-B exposure, it can be inferred from Table 3 that many compounds and biochemical processes in plants are negatively affected by UV-B radiation, including chlorophyll content and photosynthesis that led to reducing carbohydrate production, thereby affecting growth and dry weight. Besides, reducing dry weight can be explained by a reduction in $\mathrm{CO} 2$ fixation under UV-B radiation. Carbon fixation rate is affected by UV-B and the leaf age. In addition, several studies in the glasshouse and environmental chambers have shown that UV-B radiation can interfere with photosynthesis through its effects on photosystems, phosphorylation reactions, chloroplast structure, and enzyme activity (Suchar and Robberecht, 2016).

There is evidence that prolonged exposure to UV-B radiation results in reduced Rubisco activity and content (Nogués et al., 1998). This can be the reason for the dry weight reduction in UYL10. According to the findings of various studies, there are several factors impacting the dry weight of plants, including UV-B radiation dose, plant species, and plant organ. There is a wide range of responses to UV-B irradiation. Similarly, previous studies reported a significant reduction in plant biomass production under UV-B radiation (Choudhary and Agrawal, 2014; Lee et al., 2014). In another study (Nazari et al, 2018), UV-B radiation (1.15 $\mathrm{Wm}^{-2}, 2 \mathrm{~h}$ per day for three weeks) led to a reduction in shoot dry weight in Mentha aquatic. 
In contrast, Rodríguez-Calzada et al. (2018) reported that leaf dry weight of Capsicum annuит was not affected by UV radiation (1.14 $\mathrm{kj} \mathrm{m}^{-2}$ day $^{-1}, 14$ days), while stem dry weight was significantly reduced. In the study of Park et al. (2020), different levels of UV-B (0, 0.1, $0.25,0.5,1.0$, and $\left.1.25 \mathrm{~W} \mathrm{~m}^{-2}\right), 6 \mathrm{~h}$ per day for 6 days had no negative effect on the shoot dry weight in Crepidiastrum denticulatum.

Table 3. The content of chlorophyll a and $b$, and leaf dry weight (mean \pm SD) in the young and old leaves of S.verticillata under UV-B radiation (1 hour per day for 10 days).

\begin{tabular}{|c|c|c|c|c|c|c|}
\hline $\begin{array}{c}\text { Day of } \\
\text { sampling }\end{array}$ & sample & $\begin{array}{l}\text { Chlorophyll a } \\
\left(\mathrm{mg} \cdot \mathrm{g}^{-1} \mathrm{FW}\right)\end{array}$ & $\begin{array}{l}\text { Chlorophyll b } \\
\left(\mathrm{mg} \cdot \mathrm{g}^{-1} \mathrm{FW}\right)\end{array}$ & $\begin{array}{l}\text { Chlorophyll a/b } \\
\text { ratio }\end{array}$ & $\begin{array}{l}\text { Total Chlorophyll } \\
\left(\mathrm{mg} \cdot \mathrm{g}^{-1} \mathrm{FW}\right)\end{array}$ & $\begin{array}{l}\text { Leaf dry weight } \\
(\%)\end{array}$ \\
\hline 1 & $\begin{array}{l}\text { CYL } \\
\text { COL } \\
\text { UYL } \\
\text { UOL }\end{array}$ & $\begin{array}{l}0.89 \pm 0.01^{\mathrm{ab}} \\
0.93 \pm 0.04^{\mathrm{a}} \\
0.84 \pm 0.05^{\mathrm{b}} \\
0.87 \pm 0.01^{\mathrm{ab}}\end{array}$ & $\begin{array}{l}0.63 \pm 0.05^{\mathrm{ab}} \\
0.67 \pm 0.02^{\mathrm{a}} \\
0.48 \pm 0.06^{\mathrm{cd}} \\
0.59 \pm 0.05^{\mathrm{ab}}\end{array}$ & $\begin{array}{l}1.41 \pm 0.09^{\mathrm{de}} \\
1.4 \pm 0.08^{\mathrm{de}} \\
1.78 \pm 0.17^{\mathrm{bc}} \\
1.53 \pm 0.10^{\mathrm{c}-\mathrm{e}}\end{array}$ & $\begin{array}{l}1.53 \pm 0.06^{\mathrm{a}} \\
1.60 \pm 0.02^{\mathrm{a}} \\
1.31 \pm 0.10^{\mathrm{b}} \\
1.47 \pm 0.06^{\mathrm{a}}\end{array}$ & $\begin{array}{l}22.18 \pm 1.94^{\mathrm{a}-\mathrm{c}} \\
18.18 \pm 1.29^{\mathrm{de}} \\
21.74 \pm 2.27^{\mathrm{a}-\mathrm{d}} \\
17.95 \pm 1.23^{\mathrm{e}}\end{array}$ \\
\hline 5 & $\begin{array}{l}\text { CYL } \\
\text { COL } \\
\text { UYL } \\
\text { UOL }\end{array}$ & $\begin{array}{l}0.89 \pm 0.03^{\mathrm{ab}} \\
0.92 \pm 0.01^{\mathrm{a}} \\
0.68 \pm 0.03^{\mathrm{fd}} \\
0.76 \pm 0.02^{\mathrm{c}}\end{array}$ & $\begin{array}{l}0.63 \pm 0.08^{\mathrm{ab}} \\
0.65 \pm 0.03^{\mathrm{ab}} \\
0.36 \pm 0.07^{\mathrm{ef}} \\
0.46 \pm 0.06^{\mathrm{c}-\mathrm{e}}\end{array}$ & $\begin{array}{l}1.41 \pm 0.19^{\mathrm{de}} \\
1.41 \pm 0.04^{\mathrm{de}} \\
1.91 \pm 0.32^{\mathrm{b}} \\
1.66 \pm 0.17^{\mathrm{b}-\mathrm{e}}\end{array}$ & $\begin{array}{l}1.52 \pm 0.09^{\mathrm{a}} \\
1.57 \pm 0.04^{\mathrm{a}} \\
1.05 \pm 0.09^{\mathrm{de}} \\
1.23 \pm 0.08^{\mathrm{bc}}\end{array}$ & $\begin{array}{l}22.64 \pm 4.09^{\mathrm{ab}} \\
18.25 \pm 1.25^{\mathrm{de}} \\
19.94 \pm 0.38^{\mathrm{a}-\mathrm{e}} \\
16.85 \pm 1.16^{\mathrm{e}}\end{array}$ \\
\hline 10 & $\begin{array}{l}\text { CYL } \\
\text { COL } \\
\text { UYL } \\
\text { UOL }\end{array}$ & $\begin{array}{l}0.91 \pm 0.03^{\mathrm{a}} \\
0.89 \pm 0.04^{\mathrm{ab}} \\
0.65 \pm 0.04^{\mathrm{d}} \\
0.69 \pm 0.03^{\mathrm{d}}\end{array}$ & $\begin{array}{l}0.65 \pm 0.03^{\mathrm{ab}} \\
0.65 \pm 0.04^{\mathrm{ab}} \\
0.29 \pm 0.03^{\mathrm{f}} \\
0.46 \pm 0.03^{\mathrm{c}-\mathrm{e}}\end{array}$ & $\begin{array}{l}1.39 \pm 0.02^{\mathrm{de}} \\
1.36 \pm 0.03^{\mathrm{e}} \\
2.22 \pm 0.12^{\mathrm{a}} \\
1.49 \pm 0.09^{\mathrm{c}-\mathrm{e}}\end{array}$ & $\begin{array}{l}1.56 \pm 0.05^{\mathrm{a}} \\
1.54 \pm 0.09^{\mathrm{a}} \\
0.94 \pm 0.07^{\mathrm{e}} \\
1.16 \pm 0.05^{\mathrm{cd}}\end{array}$ & $\begin{array}{l}23.57 \pm 3.65^{\mathrm{a}} \\
17.45 \pm 1.23^{\mathrm{e}} \\
18.53 \pm 1.77^{\mathrm{de}} \\
16.15 \pm 0.82^{\mathrm{e}}\end{array}$ \\
\hline $\begin{array}{c}13 \\
\text { (recovery } \\
\text { time) }\end{array}$ & $\begin{array}{l}\text { CYL } \\
\text { COL } \\
\text { UYL } \\
\text { UOL }\end{array}$ & $\begin{array}{l}0.94 \pm 0.08^{\mathrm{a}} \\
0.89 \pm 0.03^{\mathrm{ab}} \\
0.70 \pm 0.03^{\mathrm{d}} \\
0.75 \pm 0.02^{\mathrm{c}} \\
\end{array}$ & $\begin{array}{l}0.57 \pm 0.13^{\mathrm{a}-\mathrm{c}} \\
0.46 \pm 0.04^{\mathrm{cd}} \\
0.43 \pm 0.07^{\mathrm{de}} \\
0.55 \pm 0.04^{\mathrm{bc}}\end{array}$ & $\begin{array}{l}1.7 \pm 0.31^{\mathrm{b}-\mathrm{d}} \\
1.95 \pm 0.14^{\mathrm{ab}} \\
1.65 \pm 0.22^{\mathrm{b}-\mathrm{e}} \\
1.37 \pm 0.05^{\mathrm{de}}\end{array}$ & $\begin{array}{l}1.55 \pm 0.14^{\mathrm{a}} \\
1.34 \pm 0.06^{\mathrm{b}} \\
1.13 \pm 0.09^{\mathrm{cd}} \\
1.31 \pm 0.07^{\mathrm{b}}\end{array}$ & $\begin{array}{l}23.02 \pm 2.36^{\mathrm{ab}} \\
18.80 \pm 1.09^{\mathrm{c}-\mathrm{e}} \\
19.62 \pm 1.42^{\mathrm{b}-\mathrm{e}} \\
16.73 \pm 1.06^{\mathrm{e}}\end{array}$ \\
\hline
\end{tabular}

Recovery time: 3 days after UV-B radiation removal. The mean values within a column followed by different letters are significantly different at the $\% 1$ probability level.

\subsection{Total phenol and flavonoid concentration in S.verticillata leaves under UV-B exposure}

According to the results (Table 4), phenolic compounds were affected by both UV-B and leaf age. Despite the negative effects of UV radiation on chlorophyll content and dry weight, the TPC and TFC were significantly increased by UV-B radiation in irradiated young and old leaves compared to the control plants. The results showed that TPC increased significantly at UYL1 and UOL1 (Table 4). Afterwards, TPC increased from $34.09 \pm 1$ to $42.82 \pm 1.81 \mathrm{mg}$ GAE. $\mathrm{g}^{-1}$ DW at UYL5. UYL5 had the highest TPC compared to old leaves and non UV-B exposed plants. With increasing the period of UV radiation (10 days), the TPC decreased to $37.69 \pm 1.89 \mathrm{mg}$ GAE. $\mathrm{g}^{-1} \mathrm{DW}$ at UYL10. Finally, TPC reached 40.63 $\pm 0.24 \mathrm{mg}$ GAE. $\mathrm{g}^{-1}$ DW at recovery time in UYL. Like young leaves, an increase and then a decline in the TPC $\left(33.41 \pm 1.99\right.$ and $31.2 \pm 4.67 \mathrm{mg}$ GAE. $\left.\mathrm{g}^{-1} \mathrm{DW}\right)$ were observed at UOL5 and UOL10, 
respectively. However, the TPC in UOL5 and UOL10 was not statistically different. With the elimination of UV-B radiation, the TPC increased to $34.18 \pm 1.42 \mathrm{mg}$ GAE. $\mathrm{g}^{-1} \mathrm{DW}$ at UOL13. As was shown in Table 4., there was an increasing trend in the TFC of young leaves under UV-B radiation as compared to the control plants. Thus, in young leaves, the lowest TFC $\left(11.97 \pm 2.37 \mathrm{mg}\right.$ QE. $\left.\mathrm{g}^{-1} \mathrm{DW}\right)$ and the highest TFC $\left(15.75 \pm 1.11 \mathrm{mg}\right.$ QE. $\left.\mathrm{g}^{-1} \mathrm{DW}\right)$ were obtained at UYL1 and UYL13, respectively. A Significant difference in TFC of UYL and CYL was maintained on the $5^{\text {th }}$ and $10^{\text {th }}$ day and recovery time. The TFC at UYL1, ULY5, ULY10 and ULY13 increased by $36.33 \%, 58.97 \%, 94.89 \%$ and $99.87 \%$ compared to CYL1, CYL5, CYL10 and CYL13, respectively. The situation was slightly different for old leaves. The TFC of UOL1 $\left(8.27 \pm 0.02 \mathrm{mg}\right.$ QE. $\left.\mathrm{g}^{-1} \mathrm{DW}\right)$ did not show a significant difference with the TFC of COL1 $\left(6.51 \pm 1.27 \mathrm{mg}\right.$ QE. $\left.\mathrm{g}^{-1} \mathrm{DW}\right)$. Although the TFC in the UOL was $67.49 \%$, $80.24 \%$ and $84.13 \%$ higher than COL on the $5^{\text {th }}$ and $10^{\text {th }}$ day and recovery time, respectively, the elimination of UV-B radiation reduced the TFC in UOL13 $\left(9.28 \pm 0.76 \mathrm{mg} \mathrm{QE} . \mathrm{g}^{-1} \mathrm{DW}\right)$ in comparison with UOL10 $\left(10.58 \pm 1.42 \mathrm{mg}\right.$ QE. $\left.\mathrm{g}^{-1} \mathrm{DW}\right)$.

Table 4. The Concentration of phenolic compounds and antioxidant activity (mean \pm SD) in the young and old leaves of S.verticillata under UV-B radiation (1 hour per day for 10 days).

\begin{tabular}{|c|c|c|c|c|}
\hline Day of sampling & sample & $\begin{array}{c}\text { Total phenol (mg } \\
\left.\text { GAE g }^{-1} \mathrm{dw}\right)\end{array}$ & $\begin{array}{l}\text { Total flavornoid } \\
\left(\mathrm{mg} \mathrm{QE} \mathrm{g}{ }^{-1} \mathrm{dw}\right)\end{array}$ & DPPH assay (\%) \\
\hline \multirow{4}{*}{1} & $\mathrm{COL}$ & $24.21 \pm 0.82^{\mathrm{i}}$ & $6.51 \pm 1.27^{\mathrm{efg}}$ & $76.07 \pm 2.55^{\mathrm{g}}$ \\
\hline & UOL & $29.55 \pm 0.53$ defgh & $8.27 \pm 0.02 \mathrm{de}$ & $81.65 \pm 1.47^{\mathrm{f}}$ \\
\hline & CYL & $28.24 \pm 1.51$ efghi & $8.78 \pm 0.88^{\mathrm{cd}}$ & $83.21 \pm 0.37^{f}$ \\
\hline & UYL & $34.09 \pm 1^{\mathrm{cd}}$ & $11.97 \pm 2.37^{b}$ & $88.19 \pm 0.31^{\mathrm{cd}}$ \\
\hline \multirow{4}{*}{5} & $\mathrm{COL}$ & $26.34 \pm 0.81$ fghi & $5.29 \pm 0.90^{\mathrm{g}}$ & $78.01 \pm 2.10^{\mathrm{g}}$ \\
\hline & UOL & $33.41 \pm 1.99^{\mathrm{cd}}$ & $8.86 \pm 0.052^{\mathrm{cd}}$ & $88.10 \pm 1.39^{\mathrm{cd}}$ \\
\hline & CYL & $31.98 \pm 5.12^{\mathrm{de}}$ & $7.80 \pm 1^{\mathrm{def}}$ & $82.51 \pm 2.12^{\mathrm{f}}$ \\
\hline & UYL & $42.82 \pm 1.81^{\mathrm{a}}$ & $12.40 \pm 1.84^{b}$ & $94.10 \pm 0.77^{\mathrm{a}}$ \\
\hline \multirow{4}{*}{10} & $\mathrm{COL}$ & $25.89 \pm 0.81$ & $5.87 \pm 0.75^{\mathrm{fg}}$ & $77.21 \pm 0.79^{g}$ \\
\hline & UOL & $31.20 \pm 4.67 \mathrm{def}$ & $10.58 \pm 1.42^{b c}$ & $84.42 \pm 1.90$ ef \\
\hline & CYL & $30.61 \pm 4.16^{\mathrm{defg}}$ & $7.43 \pm 0.44^{\mathrm{def}}$ & $81.12 \pm 4.28^{\mathrm{f}}$ \\
\hline & UYL & $37.69 \pm 1.89^{b c}$ & $14.48 \pm 0.78^{\mathrm{a}}$ & $90.06 \pm 0.31^{b c}$ \\
\hline \multirow{4}{*}{13 (recovery time) } & COL & $25.12 \pm 3.40^{\mathrm{hi}}$ & $5.04 \pm 0.90^{\mathrm{g}}$ & $77.66 \pm 0.24^{g}$ \\
\hline & UOL & $34.18 \pm 1.42^{\mathrm{cd}}$ & $9.28 \pm 0.76^{\mathrm{cd}}$ & $86.58 \pm 1.90^{\mathrm{de}}$ \\
\hline & CYL & $31.75 \pm 2.91 \mathrm{de}$ & $7.88 \pm 0.97 \mathrm{def}$ & $84.38 \pm 1.93$ ef \\
\hline & UYL & $40.63 \pm 0.24^{\mathrm{ab}}$ & $15.75 \pm 1.11^{\mathrm{a}}$ & $92.01 \pm 0.32^{\mathrm{ab}}$ \\
\hline
\end{tabular}

Recovery time: 3 days after UV-B radiation removal. The mean values within a column followed by different letters are significantly different at the $\% 1$ probability level. 
These results suggest that short-term UV-B radiation rapidly stimulated the TFC accumulation in young leaves compared to old leaves. The accumulation of flavonoids in $S$. verticillata young leaves seems to be one of the primary strategies against UV-B. The results showed that the application of supplemental UV-B for 5 days and 10 days was ideal for increasing the TPC and TFC of young leaves of S.verticillata, respectively. It was assumed that at the long-term irradiation of UV-B (10days), more phenolic compounds especially phenolic acids produced by plants were used to scavenge and neutralize reactive oxygen species which subsequently led to a decrease in the TPC. On the other hand, long-term UV radiation may increase the action of chalcone synthase and direct the pathway of the phenolic compounds into the flavonoids. These results tie well with previous studies where in plants produced phenolic compounds as defensive chemical responses in order to adapt to adverse environmental conditions such as UV (Ghasemi et al., 2019; Manukyan, 2013). The positive and significant effect of UV radiation on phenols-based bioactive compounds has been shown in many studies (Chen et al., 2018; Csepregi et al., 2017; Dolzhenko et al., 2010; Esringu et al., 2016; Ghasemzadeh et al., 2016; ). Harper (1989) indicated that young and developing leaves use phenolic compounds as a defense system, while older leaves rely on thicker cuticles and higher dry matter in environmental stress. In another study (Reifenrath and Müller, 2007), young leaves compared to old leaves exhibited a higher amount of flavonols and total glucosinolate in Sinapis alba. Besides, Sun et al. (2010) showed that flavonoids synthesis in young leaves of Ginkgo biloba L. was more affected than old leaves by UV-B. In contrast, in the study of Csepregi et al. (2017) no significant difference in flavonol content was reported with increasing leaf age of Arabidopsis thaliana. Chang et al. (2018) have demonstrated a significant decrease in free and total phenolics and an increase in bound phenolics along with leaf growing of Clausena lansium, respectively.

The phenolic compounds are present in both free and bound forms in plants. The bound phenols, unlike free phenols, are not extractable by aqueous/organic solvents mixtures. In other words, the conjugation of phenols with compounds such as pectin, cellulose, and polysaccharides can affect their hydrolysis ( $\mathrm{Su}$ et al., 2014). In the present study and most performed studies, water and organic solvents have been used to extract phenolic compounds, in which case the bonded phenolic compounds are not extracted well. It is inferred that not only the type of phenolic compounds but also their proportions are different in growth stages. Generally, the type of plant species and solvent used in extraction plays an important role in this regard. As shown in Table 4, young and old leaves of the control plants showed a 
difference in the TPC. This indicates that TPC is normally affected by leaf age in S.verticillata. In fact, UV-B radiation increases the concentration of total phenols in both young and old leaves by maintaining this difference. In other words, the process of changing the phenolic content in treated plants was similar to control plants during the experiment.

\subsection{Phenolic acids concentration in S.verticillata leaves under UV-B exposure}

The results demonstrated that UV-B exerted obvious changes in the biosynthesis of phenolic acids (Fig. 1a-d). We detected the presence of CGA, CA, RA, and SAA in all of the samples. In this study, phenolic acids showed different accumulation patterns under UV-B radiation.

In all the steps, UYLs showed the highest amount of CGA compared to the treated old leaves and control plants. Based on the results, UYL1 and UOL1 did not show a significant difference with CYL1 and COL1. Actually, the CGA synthesis was not induced by shortterm UV-B radiation. The CGA content increased significantly with increasing UV-B radiation duration at UYL5 (1.08 $\left.\mathrm{mg} . \mathrm{g}^{-1} \mathrm{DW}\right)$ and UOL5 (0.88 $\left.\mathrm{mg} . \mathrm{g}^{-1} \mathrm{DW}\right)$ compared to CYL5 (0.49 mg. $\mathrm{g}^{-1} \mathrm{DW}$ ) and COL5 (0.32 mg. $\left.\mathrm{g}^{-1} \mathrm{DW}\right)$. No significant difference in CGA was observed in UYL5, UYL10 and UYL13. However, UV-B caused a different response in old leaves. The CGA content increased significantly in UOL5 (2.75-fold) compared to COL5. The CGA content of UOL10 $\left(0.38 \pm 0.22 \mathrm{mg}\right.$. $\left.\mathrm{g}^{-1} \mathrm{DW}\right)$ was lower than that of COL10 $(0.59 \pm$ $\left.0.14 \mathrm{mg} . \mathrm{g}^{-1} \mathrm{DW}\right)$ and CYL10 $\left(0.68 \pm 0.15 \mathrm{mg}\right.$. $\left.\mathrm{g}^{-1} \mathrm{DW}\right)$. In addition to UV-B radiation, recovery time affected phenolic acids. Surprisingly, after the stop of UV-B radiation, the CGA content in UOL13 increased significantly compared to the leaves of the control plants. No significant difference in terms of CGA was observed between UOL13 and UYL13. It is noteworthy that the amount of the CGA in UOL13 increased 2.5-fold higher than that of UOL1.

The concentration of the CA and RA had an increasing and decreasing trend during UV radiation, as it was shown in Fig. 1b-c. UV-B had a more substantial impact on CA than other phenolic acids. By the beginning of exposure to UV-B, CA significantly increased in UYL1 and UOL1 compared to the control plants; however, the amount of CA in UYL1 and UOL1 was not statistically different. As shown in Fig. 1b, UYL5 and UOL5 had higher levels of CA (3.22 and 2.77-fold, respectively) than the control plants. 


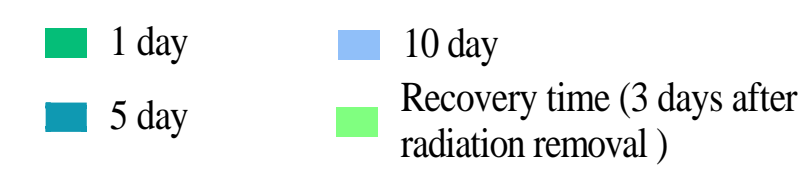

a)
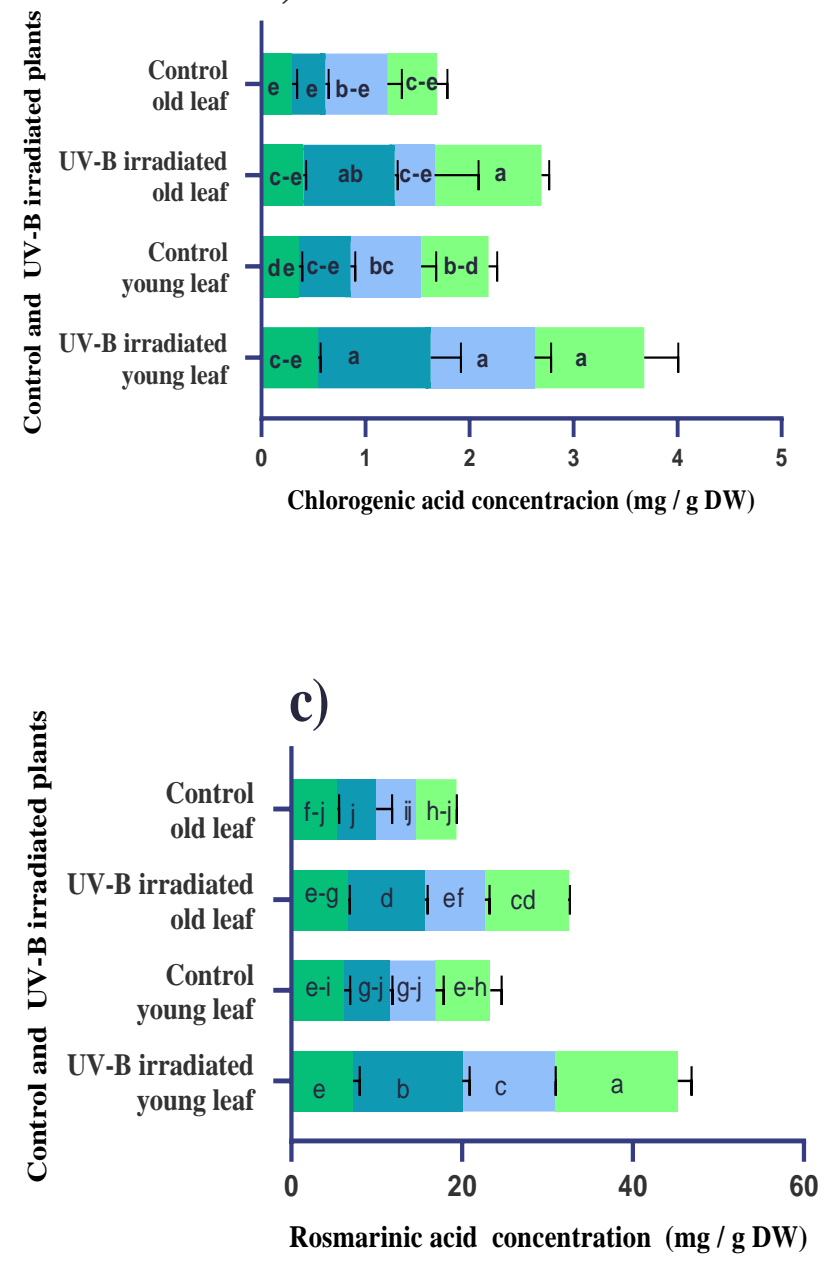

b)

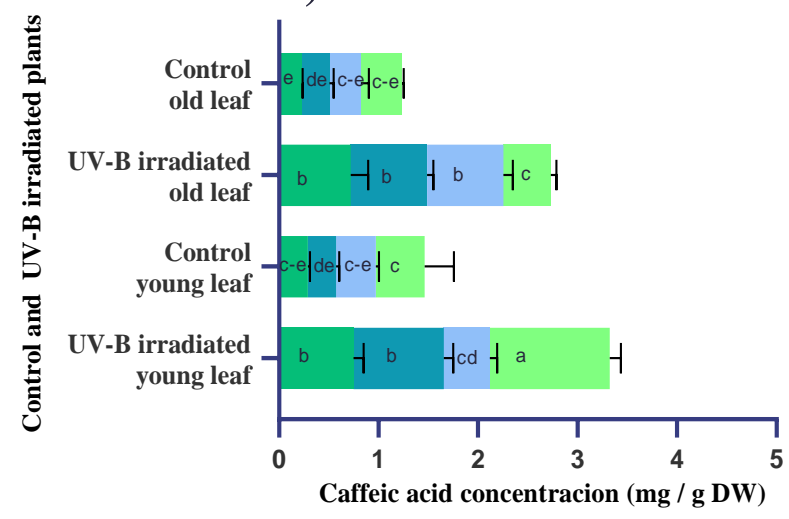

d)

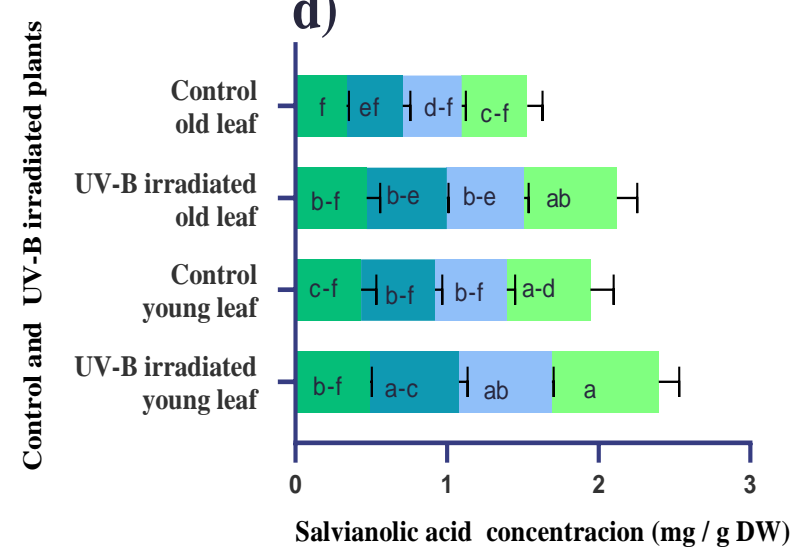

Fig.1. (a-d): The concentration of phenolic acids (mean $\pm S D, n=3$ ) in young and old leaves of S.verticillata under UV-B radiation. UV-B: 1hour per day for 10 days. Analyzes were performed on the $1^{\text {st }}, 5^{\text {th }}$ and $10^{\text {th }}$ days of the experiment in parallel with UV-B exposure and on recovery time (3 days after UV-B radiation removal or the $13^{\text {th }}$ day of experiment). a) Chlorogenic acid b) Caffeic acid c) Rosmarinic acid d) Salvianolic acid. Bars with no letters in common are significantly different $(\mathrm{p}<0.01)$.

Continuation of UV radiation until the $10^{\text {th }}$ day, led to a decrease and stability of CA in UYL10 (decreased by $48.95 \%$ compared to UYL5) and UOL, respectively. Stopping UV radiation increased the CA content (approximately 2.5-fold) at UYL13 compared to UOL13 


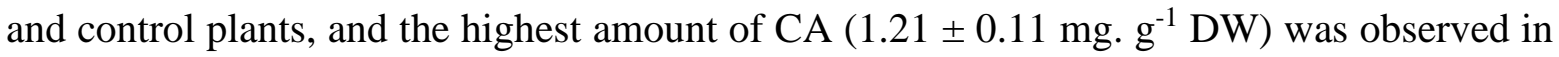
UYL13. But the treated old leaves showed a different response. Although CA was higher in UOL10 than UY10, old leaves could not maintain or increase CA amount in recovery time, and there was no significant difference between UOL13 and control plants (COL13, CYL13) in terms of CA content. Hence, it could conceivably be hypothesized that continuation of UV radiation is required to synthesize more CA in UOL. Considering that chlorogenic acids are phenolic acids that are formed by esterification of cinnamic acids, including caffeic, ferulic and p-coumaric acids with quinic acid (Sun et al., 2010) and the amount of chlorogenic acid at UOL13 increased, there is another hypothesis that old leaves tend to accumulate $\mathrm{CA}$ in another form, CGA, at recovery time. It is inferred that UV-B irradiation balances the concentration of phenolic compounds and their composition in the phenolic pool.

As can be seen from the Fig. 1c, UV-B radiation and leaf age had no significant effect on RA content at UYL1 (7.22 $\left.\pm 0.78 \mathrm{mg} . \mathrm{g}^{-1} \mathrm{DW}\right)$ and UOL1 $\left(6.69 \pm 0.1578 \mathrm{mg}\right.$. $\left.\mathrm{g}^{-1} \mathrm{DW}\right)$. After UV-B radiation exposure for 5 days, UYL5 exhibited a great increment in RA $(12.79 \pm 0.85$ mg. $\left.\mathrm{g}^{-1} \mathrm{DW}\right)$, while in prolonged irradiation (10 days), RA content $\left(10.88 \pm 0.05 \mathrm{mg}^{\mathrm{g}} \mathrm{g}^{-1} \mathrm{DW}\right)$ decreased in UYL10. Interruption of UV-B led to an increase in RA, and the highest amount of RA $\left(14.33 \pm 1.62 \mathrm{mg}\right.$. $\left.\mathrm{g}^{-1} \mathrm{DW}\right)$ was detected in UYL13. The old leaves showed similar behavior to young leaves in terms of changes in RA content, and the most amount of RA $(9.72 \pm 0.21 \mathrm{mg}$. g-1 DW) in UOL was obtained in recovery time. It is arguable that in prolonged UV-B radiation RA and CA might be used as precursors in the synthesis of other compounds, which ultimately led to less accumulation of these compounds. Unlike other phenolic acids, we observed a progressive increase in SAA under UV-B radiation. As demonstrated in Fig. 1d, the level of SAA increased even at recovery time. Although the amount of SAA in young leaves was higher in all of the steps than in old ones, this difference was not statistically significant. In other words, the amount of this substance was less affected by leaf age. The lowest $\left(0.34 \pm 0.02 \mathrm{mg} . \mathrm{g}^{-1} \mathrm{DW}\right)$ and highest $\left(0.70 \pm 0.14 \mathrm{mg} . \mathrm{g}^{-1} \mathrm{DW}\right)$ levels of SAA showed by COL1 and UYL13, respectively. Thus, to achieve the highest level of SAA, plant harvesting should be carried out in recovery time. Based on the results (Fig. 1a-d), by adjusting the duration of UV-B radiation, the synthesis pathway of phenolic compounds in old and young leaves can be directed in the desired direction. For example, the amount of CGA in young leaves can be significantly increased under UV-B radiation for 5 days, but to obtain high levels of RA, SAA and CA in young leaves, long-term ultraviolet radiation is required. 
We also found a clear impact of leaf age on phenolic compounds in this study where young leaves methanolic extracts had more UV-absorbing properties in comparison to old leaves. Agree with our findings , Berli et al. (2010) indicated that the amount and kind of phenolic compounds vary in different species, growth stages, and tissues. Since the accumulation of some metabolites was quickly stimulated by $0.5 \mathrm{~h} \mathrm{UV-B}$ radiation $\left(35 \mu \mathrm{Wcm}^{-2}\right)$ (Shamala et al., 2020), in the present study, an increase in phenolic compounds was not unexpected on the first day after treatment. Yildirim (2020) reported similar results for the effect of UV-B irradiation on the contents of CGA and RA in Echium orientale L. In the study of Park et al. (2020), UV-B (0.25 $\mathrm{Wm}^{-2}$, $6 \mathrm{~h}$ for 4 days) increased the antioxidant activity and total hydroxycinnamic acids in Crepidiastrum denticulatum. Our results support previous studies (Chen et al., 2018; Luis et al., 2007; Manukyan, 2013; Zhang et al., 2017) which showed the increase of phenolic acids such as CA and RA under UV-B radiation.

Based on the results, we infer that such rapid biochemical responses and biosynthesis of bioactive compounds in S.verticillata are essential for plant adaptation to UV-B radiation as environmental stress. It is noteworthy that after the application of UV-B radiation for ten days, no damage such as browning or curling of leaves was observed in plants, which indicates that the intensity and duration of UV-B radiation used in this study without causing damage to the plant can play an effective role in increasing the secondary metabolites.

\subsection{Antioxidant activity changes of S.verticillata leaves under UV-B radiation}

The results of the assessment of antioxidant activity using DPPH assay are shown in Table 4. According to the results, exposure to UV-B radiation significantly enhanced antioxidant activity, especially in the young leaves. Irradiation of UV-B for 5 days was favorable for the high antioxidant activity of S.verticillata young leaves extract. UYL5 and COL1 showed the highest $(94.10 \pm 0.7 \%)$ and lowest $(76.07 \pm 2.5 \%)$ antioxidant activity, respectively. From the initial day of the exposure of UV-B to the $5^{\text {th }}$ day, we observed an increase in the antioxidant activity. However, the amount of that significantly reduced in UYL10 (90.06 \pm $0.31 \%)$ and UOL10 (84.42 $\pm 1.90 \%)$. Unexpectedly, it was observed an increase in the antioxidant activity after removing the UV radiation in UYL13 $(92.01 \pm 0.32 \%)$ and UOL10 $(86.58 \pm 1.90 \%)$. 


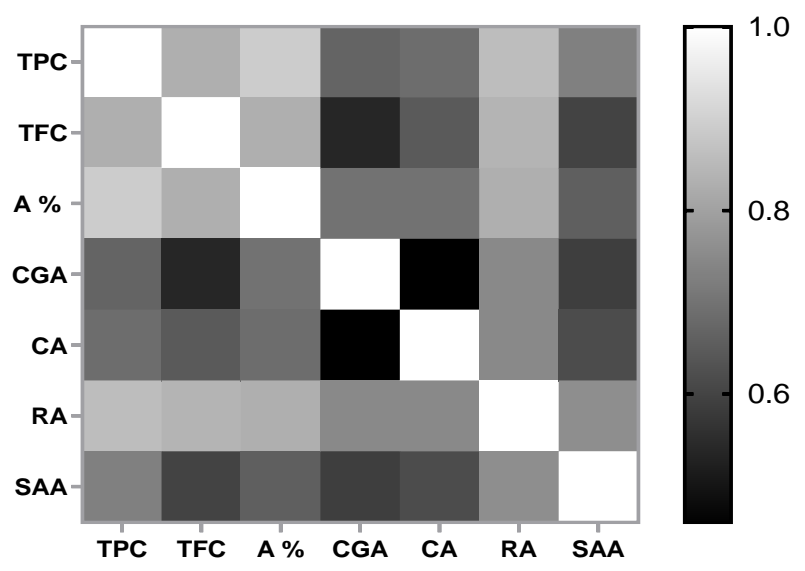

Fig. 2. Heatmap shows correlation coefficients between the phenolic compounds and antioxidant activity. Different values are represented in different colors. white means high positive correlation and black means low positive correlation. Total phenol concentration (TPC), total flavonoid concentration (TFC), chlorogenic acid (CGA), caffeic acid (CA), rosmarinic acid (RA), salvianolic acid A (SAA), \% antioxidant activity $(\mathrm{A} \%)$.

The results of the correlation analysis between the phenolic compounds and antioxidant activity were shown in Fig. 2. A positive correlation $(r=0.89)$ was recognized between the amount of phenolic compounds and antioxidant activity. RA as the predominant phenolic acid, showed the highest positive correlation $(\mathrm{r}=0.83)$ compared to other phenolic acids. These findings agree with other observations that suggested a positive correlation between antioxidant activity and phenolic content of the extracts (Csepregi et al., 2017; Esringu et al., 2016; Ghasemzadeh et al., 2016). Our findings confirmed a previous study that found a positive correlation between the total flavonoid content and the $\mathrm{DPPH}^{\bullet}$ scavenging activity (Chen et al., 2018). Actually, ROS produced by UV radiation leads to rapid signaling which activates the pathway of free radical scavenging through the biosynthesis of antioxidant compounds (Ghasemzadeh et al., 2016; Park et al., 2020). In addition, a low dose of UV-B radiation can affect antioxidant activity via the regulation of different pathways such as phenylpropanoids, cinnamates, and flavonoids (Müller-Xing et al., 2014). Pereira et al. (2009) indicated that the hydroxyl groups in phenols act as hydrogen donors and also react with active species of oxygen and nitrogen, which result in the production of an antioxidant radical form that has greater chemical stability than the primary radical. Ye et al. (2017) emphasized that flavonoids exhibit their antioxidant activity not only by scavenging free radicals but also by chelating metal ions. Shi et al. (2019) considered water-soluble phenolic acids such as RA, CA, salvianolic acids as a separate major group with high antioxidant 
activity in Salvia miltiorrhiza. On the other hand, CGA synthesis in response to environmental stresses has been proven in a wide range of plants (Kumari and Prasad, 2013).

\subsection{Changes in the expression of PAL, TAT, RAS genes in $S$. verticillata leaves under UV-B radiation}

Decrease and increase in dry weight and phenolic compounds indicate that S.verticillata modulates the expression of genes involved in both primary and secondary metabolism, under UV-B radiation. As shown in Fig. 3, UV-B radiation increased the expression of $P A L$, $T A T$ and $R A S$ genes in both young and old leaves of $S$. verticillata. In all studied genes, young leaves showed higher gene expression than old leaves. High levels of gene expression in young leaves may provide more efficient protection against UV-B radiation in young leaves. Although the $P A L$ and $R A S$ genes expression level did not significantly differ in young and old leaves at the beginning of the experiment, the effect of leaf age on gene expression especially $P A L$ and $R A S$ genes, was quite obvious on the $5^{\text {th }}$ and $10^{\text {th }}$ days.

The expression of the PAL gene in treated young and old leaves was 4.43-fold and 2.46-fold, respectively, compared to the control on the $5^{\text {th }}$ day. On the $10^{\text {th }}$ day, young leaves exhibited more gene expression than old leaves (about 2-fold) for $P A L$ gene. Whereas after recovery time, the gene expression was 1.27-fold higher. In term of $R A S$ gene, level of gene expression of irradiated young and old leaves in comparison to the control was 6.6-fold and 3.18-fold on the $5^{\text {th }}$ day, respectively. On the $10^{\text {th }}$ day and recovery time, the $R A S$ gene expression in young leaves was almost twice that of in old leaves. In all stages, the ratio of TAT gene expression of young leaves to that of old leaves was less than 1.5-fold

Obviously, the rate of increase in the TAT gene expression was lower than PAL and RAS genes. The highest transcript levels of PAL (6.66-fold), TAT (2.97-fold), and RAS (8.45-fold) genes were observed at UYL10. These results showed that young leaves were more sensitive to prolonged UV radiation than old leaves. Our outcomes suggested that $P A L$ and $R A S$ genes might be more sensitive than the TAT gene in UV-B-elicited leaves. It can be attributed to the presence of light-sensitive elements in the PAL gene promoter (Jiao et al., 2015), which lead to increase $P A L$ gene expression in response to UV radiation. Contrary to what was observed about phenolic compounds, the removal of UV-B radiation reduced the expression of genes so that in the young leaves, the lowest levels of PAL (1.23-fold) and TAT (1.43-fold) gene expression were obtained at recovery time. But, the expression of the RAS gene was not completely inhibited by the removal of UV-B, and the transcript level of RAS at UYL13 was 4.34-fold higher than that of CYL13. 

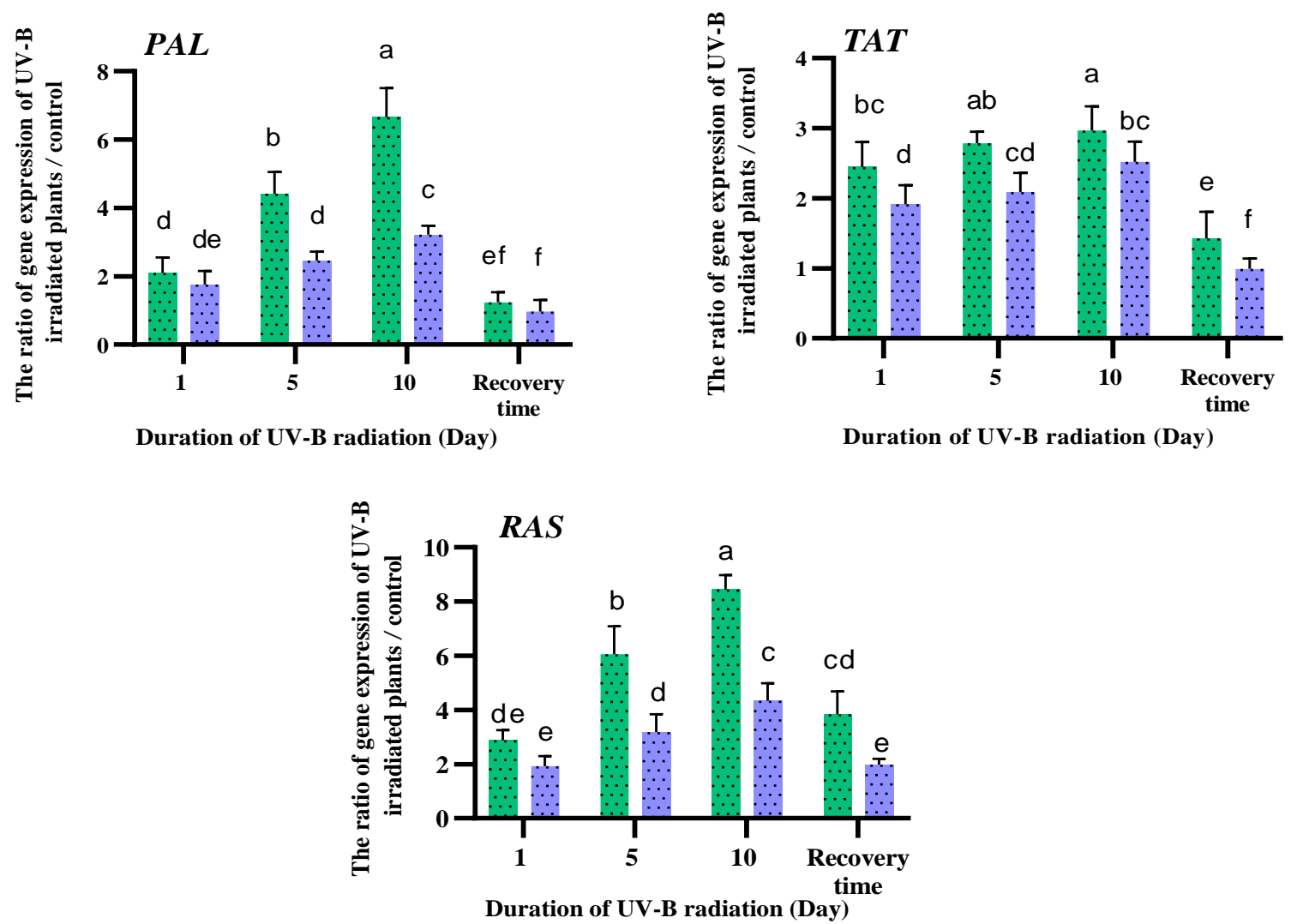

Fig.3. The relative expression of phenylalanine ammonia-lyase $(P A L)$, tyrosine aminotransferase $(T A T)$ and rosmarinic acid synthase $(R A S)$ genes in young and old leaves of S.verticillata compared to control under UV-B radiation (mean \pm SD). UV-B: 1 hour per day for 10 days. The relative expression of genes was investigated on the $1^{\text {st }}, 5^{\text {th }}$ and $10^{\text {th }}$ days of the experiment in parallel with UV-B exposure and on recovery time (3 days after UV-B radiation removal). Bars with no letters in common are significantly different $(p<0.01)$.

Our findings showed that UV-B radiation can affect the accumulation of phenolic compounds by changing the expression pattern of upstream $(P A L)$ and downstream $(R A S)$ genes of the phenylpropanoid pathway. It seems that upregulation of genes on the $10^{\text {th }}$ day had a positive effect on the synthesis of TFC, CGA and SAA, whereas the signals that triggered the biosynthesis and the accumulation of CA and RA at UYLs were less operated. Additionally, it is possible that consumption of CA and RA by the plant was more than the synthesis of them on $10^{\text {th }}$ day.

It was shown that UVR8-COP1-HY5 plays an important role in transmitting the initial signal pathway to UV adaptive responses (Lee, 2016). In a study by Kumari and Prasad (2013), it was demonstrated that signals generated by ultraviolet light increase the expression of several major genes in the secondary metabolite pathways. As stated by Berli et al. (2010), UV-B 
prompts the expression of genes encoding regulatory enzymes of the phenylpropanoid pathway, such as PAL and chalcone synthase. Our outcomes are in agreement with the findings of Dolzhenko et al. (2010), which reported plants respond to the UV-B by regulation of gene expression related to secondary metabolites. Ghasemi et al. (2019) reported that PAL as a key enzyme plays a vital role in the synthesis of phenolic acids and flavonoids and acts as a defensive gene against environmental stresses, such as UV radiation.

Current findings were similar to publications that reported the positive effect of UV radiation on PAL gene expression (Cantarello et al., 2005; Esringu et al., 2016; Ghasemi et al., 2019; Rodríguez-Calzada et al., 2018 Surjadinata et al., 2017). Moreover, TAT gene expression has been reported in all tested organs of Salvia miltiorrhiza under UV radiation, with the highest level of expression in stems (Huang et al., 2008).

In some studies, the PAL pathway has been considered as a rate-limiting step in the RA synthesis (Shi et al., 2019; Xu et al., 2016). In contrast, Rahmani et al. (2020) have reported that although the enzymes PAL and TAT are essential for the synthesis of RA, they could not act as rate-limiting steps. Our findings showed that both $P A L$ and TAT enzymes play a role in the biosynthesis of RA in two parallel pathways. However, considering the RT-qPCR results, it is clear that the $P A L$ enzyme has been more active in the biosynthesis of RA in S.verticillata under UV radiation.

\section{Conclusion}

UV-B radiation significantly altered the productivity of phenolic compounds in S.verticillata. Besides, the age factor obviously influenced genes expression level and accumulation of bioactive compounds with higher values recorded in young leaves. Results demonstrated that UV-B as an environmental elicitor induced the transcription of $P A L, T A T$ and $R A S$ genes that finally enhanced the accumulation of studied phenolic compounds in S.verticillata leaves. In addition to total phenol and flavonoid contents, phenolic acids also were promoted by UV-B exposure with greater value in young leaves. Another beneficial effect of UV-B radiation on the S.verticillata was the increasing of the $\mathrm{DPPH}^{\bullet}$ scavenging activity, which had a positive correlation with phenolic compounds. Despite the positive effects of UV-B radiation on phenolic compounds, chlorophyll content and dry weight $(\%)$ reduced under UV-B radiation. These results enhance our understanding of the role of UV-B radiation in S.verticillata plant, so that in environments with more UV-B radiation, an increase in phenolic compounds can be 
predicted in other plants. Although UV-B radiation can damage plants, the use of appropriate doses can increase the valuable compounds in medicinal plants. In other words, unfavorable environmental factors can be used as an opportunity to stimulate the synthesis of bioactive compounds in medicinal plants. The results of the present study can be beneficial for secondary metabolite production with higher quality under controlled environmental status.

\author{
Abbreviations Used \\ $\mathrm{Chl}^{1} ; \mathrm{TPC}^{2} ; \mathrm{TFC}^{3} ; \mathrm{DPPH}^{4} ; \mathrm{RP}^{2} \mathrm{HPLC}^{5} ; \mathrm{CGA}^{6} ; \mathrm{CA}^{7} ; \mathrm{RA}^{8} ; \mathrm{SAA}^{9} ; \mathrm{ROS}^{10} ; \mathrm{PAL}^{11} ; \mathrm{TAT}^{12}$; \\ $R A S^{13} ; \mathrm{RT}^{-q P C R}{ }^{14} ; \mathrm{PCR}^{15}$
}

\title{
Author contribution statement
}

M. Rahimi Rizi made contribution to the conception of the study, collection and interpretation of data, and the writing of the manuscript. M. Sayyari contributed to the experimental work. A. Mirzaie-Asl and L. Conti contributed to the experimental work, implementation of the research and final revising the manuscript. A. Azizi involved in planning and supervising the work. All authors read and approved the final manuscript. The authors declare no conflict of interest.

\section{Declaration of Competing Interest}

The authors declare that they have no conflict of interest.

\section{Acknowledgement}

The authors thank the Bu Ali Sina University for financial support of this project. This work is part of Miss. Marziye Rahimi Ph.D. thesis.

\section{References}

\footnotetext{
${ }^{1}$ Chlorophyll

2 Total Phenol concentration

${ }^{3}$ Total Flavonoid concentration

${ }^{4}$ 1,1-diphenyl-2-picrylhydrazyl

${ }^{5}$ Reverse phase high performance liquid chromatography

${ }^{6}$ Chlorogenic acid

${ }^{7}$ Caffeic acid

${ }^{8}$ Rosmarinic acid

${ }^{9}$ Salvianolic acid A

${ }^{10}$ Reactive oxygen species

${ }^{11}$ Phenylalanine ammonia-lyase

12 Tyrosine aminotransferase

${ }^{13}$ Rosmarinic acid synthase

${ }^{14}$ Real-time quantitative PCR

${ }^{15}$ Polymerase chain reaction
} 
Berli, F.J., Moreno, D., Piccoli, P., Hespanhol-Viana, L., Silva, M.F., Bressan-Smith, R., Cavagnaro, J.B., Bottini, R., 2010. Abscisic acid is involved in the response of grape (Vitis vinifera L.) cv. Malbec leaf tissues to ultraviolet-B radiation by enhancing ultraviolet- absorbing compounds, antioxidant enzymes and membrane sterols. Plant, Cell Environ. 33, 1-10. https://doi.org/10.1111/j.1365-3040.2009.02044.x

Cantarello, C., Volpe, V., Azzolin, C., Bertea, C.M., 2005. Modulation of enzyme activities and expression of genes related to primary and secondary metabolism in response to UV-B stress in cucumber (Cucumis sativus L.). J. Plant Interact. 1, 151-161. https://doi.org/10.1080/17429140600831581

Chang, X., Lu, Y., Lin, Z., Qiu, J., Guo, X., Pan, J., Abbasi, A.M., 2018. Impact of leaf development stages on polyphenolics profile and antioxidant activity in Clausena lansium (Lour.) skeels. Biomed Res. Int. 2018. https://doi.org/10.1155/2018/7093691

Chen, Y., Zhang, X., Guo, Q., Liu, L., Li, C., Cao, L., Qin, Q., Zhao, M., Wang, W., 2018. Effects of UV-B radiation on the content of bioactive components and the antioxidant activity of Prunella vulgaris L. Spica during development. Molecules 23, 1-11. https://doi.org/10.3390/molecules23050989

Choudhary, K.K., Agrawal, S., 2014. Ultraviolet-B induced changes in morphological, physiological and biochemical parameters of two cultivars of pea (Pisum sativum L.). Ecotoxicol Environ Saf. 100, 178-187. https://doi.org/10.1016/j.ecoenv.2013.10.032

Csepregi, K., Coffey, A., Cunningham, N., Prinsen, E., Hideg, É., Jansen, M.A.K., 2017. Developmental age and UV-B exposure co-determine antioxidant capacity and flavonol accumulation in Arabidopsis leaves. Environ. Exp. Bot. 140, 19-25. https://doi.org/10.1016/j.envexpbot.2017.05.009

Cuadra, P., Herrera, R., Fajardo, V., 2004. Effects of UV-B radiation on the Patagonian Jaborosa magellanica Brisben. J Photochem Photobiol. B. 76, 61-68.10. https://doi.org/1016/j.jphotobiol.2004.05.016

Dolzhenko, Y., Bertea, C.M., Occhipinti, A., Bossi, S., Maffei, M.E., 2010. UV-B modulates the interplay between terpenoids and flavonoids in peppermint (Menthaxpiperita L.). J. Photochem. Photobiol. B Biol. 100, 67-75. https://doi.org/10.1016/j.jphotobiol.2010.05.003

Ebrahimabadi, A.H., Mazoochi, A., Kashi, F.J., Djafari-Bidgoli, Z., Batooli, H., 2010. Essential oil composition and antioxidant and antimicrobial properties of the aerial parts of Salvia eremophila Boiss. from Iran. Food Chem. Toxicol. 48, 1371-1376. https://doi.org/10.1016/j.fct.2010.03.003

Esringu, A., Aksakal, O., Tabay, D., Kara, A.A., 2016. Effects of sodium nitroprusside (SNP) pretreatment on UV-B stress tolerance in lettuce (Lactuca sativa L.) seedlings. Environ. Sci. Pollut. Res. 23, 589-597. https://doi.org/10.1007/s11356-015-5301-1

Farah, A., Donangelo, C.M., 2006. Phenolic compounds in coffee. Brazilian J. Plant Physiol. 18, $23-36$. https://doi.org/10.1590/S1677-04202006000100003

Flores-Bocanegra, L., González-Andrade, M., Bye, R., Linares, E., Mata, R., 2017. $\alpha$-Glucosidase Inhibitors from Salvia circinata. J. Nat. Prod. 80, 1584-1593. https://doi.org/10.1021/acs.jnatprod.7b00155

Fotovvat, M., Radjabian, T., Saboora, A., 2019. HPLC fingerprint of important phenolic compounds in some Salvia L. Species from iran. Rec. Nat. Prod. 13, 37-49. https://doi.org/10.25135/rnp.72.18.02.228

Ghasemi, S., Kumleh, H.H., Kordrostami, M., 2019. Changes in the expression of some genes involved in the biosynthesis of secondary metabolites in Cuminum cyminum L. under UV stress. Protoplasma 256, 279290. https://doi.org/10.1007/s00709-018-1297-y

Ghasemzadeh, A., Ashkani, S., Baghdadi, A., Pazoki, A., Jaafar, H.Z.E., Rahmat, A., 2016. Improvement in flavonoids and phenolic acids production and pharmaceutical quality of sweet basil (Ocimum basilicum L.) by ultraviolet-B irradiation. Molecules 21. https://doi.org/10.3390/molecules21091203

Ghorbani, A., Esmaeilizadeh, M., 2017. Pharmacological properties of Salvia officinalis and its components. J. Tradit. Complement. Med. 7, 433-440. https://doi.org/10.1016/j.jtcme.2016.12.014

Hamidpour, M., Hamidpour, R., Hamidpour, S., Shahlari, M., 2014. Chemistry, pharmacology, and medicinal property of sage (salvia) to prevent and cure illnesses such as obesity, diabetes, depression, dementia, lupus, autism, heart disease, and cancer. J. Tradit. Complement. Med. 4, 82-88. https://doi.org/10.4103/2225-4110.130373

Harper, J.L., 1989. The value of a leaf. Oecologia 80, 53-58. https://doi.org/10.1007/BF00789931

Hofmann, R.W., Campbell, B.D., Bloor, S.J., Swinny, E.E., Markham, K.R., Ryan, K.G., Fountain, D.W., 2003. Responses to UV-B radiation in Trifolium repens L. - Physiological links to plant productivity and water availability. Plant, Cell Environ. 26, 603-612. https://doi.org/10.1046/j.1365-3040.2003.00996.x

Hopkins, L., Bond, M.A., Tobin, A.K., 2002. Ultraviolet-B radiation reduces the rates of cell division and elongation in the primary leaf of wheat (Triticum aestivum L. cv Marls Huntsman). Plant, Cell Environ. 25, 617-624. https://doi.org/10.1046/j.1365-3040.2002.00834.X

Huang, B., Yi, B., Duan, Y., Sun, L., Yu, X., Guo, J., Chen, W., 2008. Characterization and expression profiling of tyrosine aminotransferase gene from Salvia miltiorrhiza (Dan-shen) in rosmarinic acid biosynthesis pathway. Mol. Biol. Rep. 35, 601-612. https://doi.org/10.1007/s11033-007-9130-2 
Jassbi, A.R., Zare, S., Firuzi, O., Xiao, J., 2016. Bioactive phytochemicals from shoots and roots of Salvia species. Phytochem. Rev. 15, 829-867. https://doi.org/10.1007/s11101-015-9427-Z

Jiao, J., Gai, Q.Y., Wang, W., Luo, M., Gu, C.B., Fu, Y.J., Ma, W., 2015. Ultraviolet radiation-elicited enhancement of isoflavonoid accumulation, biosynthetic gene expression, and antioxidant activity in astragalus membranaceus hairy Root cultures. J. Agric. Food Chem. 63, 8216-8224. https://doi.org/10.1021/acs.jafc.5b03138

Kamble, P.N., Giri, S.P., Mane, R.S., Tiwana, A., 2015. Estimation of chlorophyll content in young and adult leaves of some selected plants. Univers. j. environ. res. technol. 5, 306-310. https://doi.org/10.1016/j.plantsci.2014.06.014.

Katanić Stanković, J.S., Srećković, N., Mišić, D., Gašić, U., Imbimbo, P., Monti, D.M., Mihailović, V., 2020. Bioactivity, biocompatibility and phytochemical assessment of lilac sage, Salvia verticillata L. (Lamiaceae) - A plant rich in rosmarinic acid. Ind. Crops Prod. 143. https://doi.org/10.1016/j.indcrop.2019.111932

Klein, F.R.S., Reis, A., Kleinowski, A.M., Telles, R.T., Amarante, L. Do, Peters, J.A., Braga, E.J.B., 2018. Uvb radiation as an elicitor of secondary metabolite production in plants of the genus alternanthera. Acta Bot. Brasilica 32, 615-623. https://doi.org/10.1590/0102-33062018abb0120

Kocak, M.S., Sarikurkcu, C., Cengiz, M., Kocak, S., Uren, M.C., Tepe, B., 2016. Salvia cadmica: Phenolic composition and biological activity. Ind. Crops Prod. 85, $204-212$. https://doi.org/10.1016/j.indcrop.2016.03.015

Kolb, C.A., Käser, M.A., Kopecký, J., Zotz, G., Riederer, M., Pfündel, E.E., 2001. Effects of natural intensities of visible and ultraviolet radiation on epidermal ultraviolet screening and photosynthesis in grape leaves. Plant Physiol. 127, 863-875. https://doi.org/10.1104/pp.010373

Koutsoulas, A., Čarnecká, M., Slanina, J., Tóth, J., Slaninová, I., 2019. Characterization of phenolic compounds and antiproliferative effects of salvia pomifera and salvia fruticosa extracts. Molecules 24. https://doi.org/10.3390/molecules24162921

Kowalski, R., Kowalska, G., Jankowska, M., Nawrocka, A., Kałwa, K., Pankiewicz, U., Włodarczyk-Stasiak, M., 2019. Secretory structures and essential oil composition of selected industrial species of lamiaceae. Acta Sci. Pol. Hortorum Cultus 18, 53-69. https://doi.org/10.24326/asphc.2019.2.6

Kumari, R., Prasad, M.N.V., 2013. Medicinal plant active compounds produced by UV-B exposure. In Sustainable agriculture reviews. Springer, Dordrecht. 225-254. https://doi.org/10.1007/978-94-007-5961$\underline{98}$

Kwon, D.Y., Kim, Y.B., Kim, J.K., Park, S.U., 2020. Production of rosmarinic acid and correlated gene expression in hairy root cultures of green and purple basil (Ocimum basilicum L.). Prep. Biochem. Biotechnol. 0, 1-9. https://doi.org/10.1080/10826068.2020.1789990

Lee, J.H., 2016. UV-B signal transduction pathway in arabidopsis. J. Plant Biol. 59, $223-230$. https://doi.org/10.1007/s12374-016-0155-8

Lee, M.J., Son, J.E., Oh, M.M., 2014. Growth and phenolic compounds of Lactuca sativa L. grown in a closedtype plant production system with UV-A, -B, or -C lamp. J Sci Food Agric. 94, 197-204. https://doi.org/10.1002/jsfa.6227

Lichtenthaler, H.K., 1987. [34] Chlorophylls and carotenoids: Pigments of photosynthetic biomembranes, Methods in Enzymology. Academic Press. 148, 350-382. https://doi.org/10.1016/0076-6879(87)48036-1.

Livak, K.J., Schmittgen, T.D., 2001. Analysis of relative gene expression data using real-time quantitative PCR and the 2- $\Delta \Delta$ CT method. Methods 25, 402-408. https://doi.org/10.1006/meth.2001.1262

Luis, J.C., Pérez, R.M., González, F.V., 2007. UV-B radiation effects on foliar concentrations of rosmarinic and carnosic acids in rosemary plants. Food Chem. 101, 1211-1215. https://doi.org/10.1016/j.foodchem.2006.03.023

Mackerness, S.A.H., 2000. Plant responses to ultraviolet-B (UV-B: 280-320 nm) stress: What are the key regulators?. Plant Growth Regul. 32, 27-39. https://doi.org/10.1023/A:1006314001430

Mahdavian, K., Ghorbanli, M., Kalantari, K.M., 2008. The effects of ultraviolet radiation on the contents of chlorophyll, flavonoid, anthocyanin and proline in Capsicum annuum L. Turk J Botany. 32, 25-33.

Manukyan, A., 2013. Effects of PAR and UV-B radiation on herbal yield, bioactive compounds and their antioxidant capacity of some medicinal plants under controlled environmental conditions. Photochem. Photobiol. 89, 406-414. https://doi.org/10.1111/j.1751-1097.2012.01242.x

Martins, F., Oliveira, I., Barros, A., Amaral, C., Afonso, S., Ferreira, H., Moutinho-Pereira, J., GonÇAlves, B., 2017. Leaf morpho-physiological dynamics in Salvia officinalis L. var. purpurascens. Turk J Botany. 41, 134-144. https://doi.org/10.3906/bot-1607-24

McKenzie, R.L., Björn, L.O., Bais, A., Ilyasd, M., 2003. Changes in biologically active ultraviolet radiation reaching the Earth's surface. Photochem. Photobiol. Sci. 2, 5-15. https://doi.org/10.1039/b211155c

McKenzie, R.L., Liley, J. Ben, Björn, L.O., 2009. UV radiation: Balancing risks and benefits. Photochem. Photobiol. 85, 88-98. https://doi.org/10.1111/j.1751-1097.2008.00400.x 
Mosadegh, H., Trivellini, A., Ferrante, A., Lucchesini, M., Vernieri, P., Mensuali, A., 2018. Applications of UV-B lighting to enhance phenolic accumulation of sweet basil. Sci. Hortic. (Amsterdam). 229, 107-116. https://doi.org/10.1016/j.scienta.2017.10.043

Müller-Xing, R., Xing, Q., Goodrich, J., 2014. Footprints of the sun: Memory of UV and light stress in plants. Front. Plant Sci. 5, 1-12. https://doi.org/10.3389/fpls.2014.00474

Nogués, S., Allen, D.J., Morison, J.I., Baker, N.R., 1998. Ultraviolet-B radiation effects on water relations, leaf development, and photosynthesis in droughted pea plants. Plant Physiol. 117, 173-181. https://doi.org/10.1104/pp.117.1.173

Pandey ,N., Pandey-Rai, S., 2013. Short term UV-B radiation-mediated transcriptional responses and altered secondary metabolism of in vitro propagated plantlets of Artemisia anпиa L. Plant Cell Tissue Organ Cult. 116, 371-385. https://doi.org/10.1007/s11240-013-0413-0

Park, S.Y., Lee, M.Y., Lee, C.H., Oh, M.M., 2020. Physiologic and metabolic changes in crepidiastrum denticulatum according to different energy levels of UV-B radiation. Int. J. Mol. Sci. 21, 1-16. https://doi.org/10.3390/ijms21197134

Pereira, D.M., Valentão, P., Pereira, J.A., Andrade, P.B., 2009. Phenolics: From chemistry to biology. Molecules 14, 2202-2211. https://doi.org/10.3390/molecules14062202

Rahmani, N., Radjabian, T., Soltani, B.M., 2020. Impacts of foliar exposure to multi-walled carbon nanotubes on physiological and molecular traits of Salvia verticillata L., as a medicinal plant. Plant Physiol. Biochem. 150, 27-38. https://doi.org/10.1016/j.plaphy.2020.02.022

Reifenrath, K., Müller, C., 2007. Species-specific and leaf-age dependent effects of ultraviolet radiation on two Brassicaceae. Phytochemistry 68, 875-885. https://doi.org/10.1016/j.phytochem.2006.12.008

Rodríguez-Calzada, T., Qian, M., Strid, Å., Neugart, S., Schreiner, M., Torres-Pacheco, I., Guevara-González, R.G., 2018. Effect of UV-B radiation on morphology, phenolic compound production, gene expression, and subsequent drought stress responses in chili pepper (Capsicum annuum L.). Plant Physiol. Biochem. 134, 94-102. https://doi.org/10.1016/j.plaphy.2018.06.025

Shamala, L.F., Zhou, H.C., Han, Z.X., Wei, S., 2020. UV-B Induces Distinct Transcriptional Re-programing in UVR8-Signal Transduction, Flavonoid, and Terpenoids Pathways in Camellia sinensis. Front. Plant Sci. 11, 1-15. https://doi.org/10.3389/fpls.2020.00234

Shi, M., Huang, F., Deng, C., Wang, Y., Kai, G., 2019. Bioactivities, biosynthesis and biotechnological production of phenolic acids in Salvia miltiorrhiza. Crit. Rev. Food Sci. Nutr. 59, 953-964. https://doi.org/10.1080/10408398.2018.1474170

Su, D., Zhang, R., Hou, F., Zhang, M., Guo, J., Huang, F., Deng, Y., Wei, Z., 2014. Comparison of the free and bound phenolic profiles and cellular antioxidant activities of litchi pulp extracts from different solvents. BMC Complement. Altern. Med. 14, 1-10. https://doi.org/10.1186/1472-6882-14-9

Suchar, V.A., Robberecht, R., 2016. Integration and scaling of UV-B radiation effects on plants: from molecular interactions to whole plant responses. Ecol Evol. 6, 4866-4884. https://doi.org/10.1002/ece3.2064

Sun, M., Gu, X., Fu, H., Zhang, L., Chen, R., Cui, L., Zheng, L., Zhang, D., Tian, J., 2010. Change of secondary metabolites in leaves of Ginkgo biloba L. in response to UV-B induction. Innov. Food Sci. Emerg. Technol. 11, 672-676. https://doi.org/10.1016/j.ifset.2010.08.006

Surjadinata, B.B., Jacobo-Velázquez, D.A., Cisneros-Zevallos, L., 2017. UVA, UVB and UVC light enhances the biosynthesis of phenolic antioxidants in fresh-cut carrot through a synergistic effect with wounding. Molecules 22, 1-13. https://doi.org/10.3390/molecules22040668

Takshak, S., Agrawal, S.B., 2015. Defence strategies adopted by the medicinal plant Coleus forskohlii against supplemental ultraviolet-B radiation: Augmentation of secondary metabolites and antioxidants. Plant Physiol Biochem. 97, 124-138. https://doi.org/10.1016/j.plaphy.2015.09.018

Topçu, G., 2006. Bioactive triterpenoids from Salvia species. J. Nat. Prod. 69, $482-487$. https://doi.org/10.1021/np0600402

Xu, D., Li, Y., Meng, X., Zhou, T., Zhou, Y., Zheng, J., Zhang, J., 2017. Natural antioxidants in foods and medicinal plants: extraction, assessment and resources. Int. J. Mol. Sci. 18, $20-31$. https://doi.org/10.3390/ijms18010096

Xu, J., Wei, K., Zhang, G., Lei, L., Yang, D., Wang, W., Han, Q., Xia, Y., Bi, Y., Yang, M., Li, M., 2018. Ethnopharmacology, phytochemistry, and pharmacology of Chinese Salvia species: A review. J. Ethnopharmacol. 225, 18-30. https://doi.org/10.1016/i.jep.2018.06.029

Xu, Z., Ji, A., Zhang, X., Song, J., Chen, S., 2016. Biosynthesis and regulation of active compounds in medicinal model plant Salvia miltiorrhiza. Chinese Herb. Med. 8, 3-11. https://doi.org/10.1016/s16746384(16)60002-3

Yang, Y., Hou, S., Cui, G., Chen, S., Wei, J., Huang, L., 2010. Characterization of reference genes for quantitative real-time PCR analysis in various tissues of Salvia miltiorrhiza. Mol. Biol. Rep. 37, 507-513. https://doi.org/10.1007/s11033-009-9703-3

Ye, Y., Sun-Waterhouse, D., You, L., Abbasi, A.M., 2017. Harnessing food-based bioactive compounds to 
reduce the effects of ultraviolet radiation: a review exploring the link between food and human health. Int. J. Food Sci. Technol. 52, 595-607. https://doi.org/10.1111/ijfs.13344

Yildirim, A.B., 2020. Ultraviolet-B-induced changes on phenolic compounds, antioxidant capacity and HPLC profile of in vitro-grown plant materials in Echium orientale L. Ind. Crops Prod. 153, 112584. https://doi.org/10.1016/j.indcrop.2020.112584

Zahra, W., Rai, S.N., Birla, H., Singh, S. Sen, Rathore, A.S., Dilnashin, H., Keswani, C., Singh, S.P., 2020. Bioeconomy for sustainable development. Springer Singapore, Singapore.

Zhang, X.R., Chen, Y.H., Guo, Q.S., Wang, W.M., Liu, L., Fan, J., Cao, L.P., Li, C., 2017. Short-term uv-b radiation effects on morphology, physiological traits and accumulation of bioactive compounds in prunella vulgaris 1. J. Plant Interact. 12, 348-354. https://doi.org/10.1080/17429145.2017.1365179

Ziba Jamzad, 2012. Flora of Iran: Lamiaceae. Research Institute of Forests and Rangelands, Tehran. 